\title{
Examining Linkages between Psychological Health Problems, Socio-Demographic Characteristics and Workplace Stressors in Pakistan's Academia
}

\author{
Anwar Khan ${ }^{1}$, Rosman Bin Md Yusoff ${ }^{1} \&$ Khairunesa Binti Isa ${ }^{1}$ \\ ${ }^{1}$ Fakulti Sains, Teknologi Dan Pembangunan Insan, Universiti Tun Hussein Onn Malaysia, Malaysia \\ Correspondence: Anwar Khan, Fakulti Sains, Teknologi Dan Pembangunan Insan, Universiti Tun Hussein Onn \\ Malaysia, Malaysia. E-mail: akpashtoon1981@gmail.com
}

Received: October 8, 2015 Accepted: January 8, 2016 Online Published: May 26, 2016

doi:10.5539/ies.v9n6p108 URL: http://dx.doi.org/10.5539/ies.v9n6p108

\begin{abstract}
Scholarly work and research are globally known as stressful and challenging. Teachers may develop different psychological health problems once they are exposed to workplace stressors. Considering it as a serious issue of education sector, this study has examined the linkages between prevalent workplace stressors and psychological health problems in Pakistan's academia. A cross-section quantitative research design was adopted, whereas data was collected by self-administered questionnaire from a sample of 1189 teachers working within 12 universities of Pakistan. Descriptive statistics were used for analysis of demographic data; Chi-square tests were performed to compare psychological health problems with socio-demographic characteristics, whereas Multivariate Logistic Regression Analysis was run to know the relationship between prevalent work stressors and psychological health problems. Results show that the majority of respondents were male (63.8\%), unmarried (58.5\%), 25 to 40 years old (78.5\%) and working as Lecturers or Assistant Professors (77\%), thus their average job experience was 05 to 10 years. Psychological health problems were prevailing more among male, unmarried, less experienced and junior teachers. Such socio-demographic characteristics were potential risk factors for psychological health problems. Furthermore, respondents exposed to work stressors like workload, interpersonal and emotional demands were more likely to develop psychological health problems. Findings of the current study will develop awareness among teachers concerning work stress and psychological health. Such findings can be utilized by policy makers of Pakistan for devising policies about occupational health \& safety of teachers. The prevalence of psychological health problems in academia of Pakistan is a recognized workplace issue. Therefore, it needs immediate corrective measures at individual and institutional levels.
\end{abstract}

Keywords: psychological health, work stressors, academic staff, higher education system, multivariate logistics regression

\section{Introduction}

Since last few years, it has been observed that the psychological health problems have gradually increased in teaching profession (Bauer et al., 2007; Kataoka, Ozawa, Tomotake, Tanioka, \& King, 2014; Kovess-Masféty, Sevilla-Dedieu, Rios-Seidel, Nerrière, \& Chee, 2006; Moreno-Abril et al., 2007). The challenges of twenty first century has changed the working environments within universities, that is why academic and research work has become stressful, where university teachers work under strict work schedule, with resources constraints, multiple roles and workload (Winefield, Boyd, Saebel, \& Pignata, 2008). Once the academicians are exposed work stressors, then they develop symptoms of Anxiety, Melancholy, Social Dysfunction, Detachment and Isolation (Gillespie, Walsh, Winefield, Dua, \& Stough, 2001), eventually, their work performance is negatively affected. It has been reported that teachers suffering from stress cannot control students in class, they give physical punishment, deliver poor lectures and their social dealing is not good (MacAnespie, 1978). Teachers suffering from stress and psychological problems have negative institutional outcomes in terms of absenteeism, health claims and lesser productivity (Henderson, Harvey, Øverland, Mykletun, \& Hotopf, 2011).

Like rest of the world, the universities inside Pakistan have experienced a paradigm shift during year 2002, when Higher Education Commission was established for uplifting the education system in Pakistan. The Government took such steps to enable the Higher Education System of Pakistan to meet the challenges of twenty first century. 
For this purpose huge budgets were allocated to Higher Education Commission and Ministry of Education, which resulted in increase in number of universities from 82 during year 2002 to 114 in year 2006 and 154 in year 2013. The budget was increased from 28 million rupees during 2006-2007 to 33 million in 2009-2010 (PES, 2013). Apart from this curriculum up gradations were done by offering diverse range of academic and research programs, so that research and creativity of students may be maximized. In this regard special linkages were made with industry so that academia could solve the problem of industry (Laghar, 2013). Such improvements were done to increase the outcomes of universities, which will cause positive impact on the socio-economic lives of Pakistani citizens. In this whole process, the higher educational institutions of Pakistan remained under persistent pressure. The teachers and other staff members were eventually subjected to work pressure because they were expected to work more under time constraints and tight institutional policies, so that challenges of twenty first century could be successfully met (Khan, Yusoff, \& Azam, 2014). Therefore, the teachers started experiencing a state of exhaustion, followed by symptoms of anxiety, isolation, depression and social dysfunction (Yusoff, Khan, \& Azam, 2013). The previous research shows that if such situation prevails within higher educational system of any country, then individual working lives of teachers and the overall productivity of universities might get affected

The seriousness of this issue could be recognized from the fact that in past a large number of research studies have been conducted on psychological health problems in teaching profession. The findings of these studies show that certain socio-demographic characteristics e.g. age, gender, marital status, job position and work experience (Kataoka et al., 2014; Kovess-Masféty et al., 2006; Reevy \& Deason, 2014) become risk factors of psychiatric morbidity among academic staff members. Apart from this, certain work related factors e.g. career cycle, working environment features (Kovess-Masféty et al., 2006), workload, interaction with students, non-teaching duties, appraisal by boss (Moreno-Abril et al., 2007), job insecurity, lack of autonomy (Rusli, Edimansyah, \& Naing, 2006) etc. also become potential risk factors of psychological health problems in teaching profession. Thus, psychological problems in teaching occupation cannot be left unchecked because it may weaken the productivity of educational institutions and affect the working lives of academic staff members.

The current study has examined the prevalence and risk factors for psychological problems among teachers working in twelve universities of Pakistan. For this purpose, a quantitative cross sectional design was used by collecting self-reported data from 1189 teachers on socio-demographic characteristics, work stressors and psychological health problems. Pearson Chi-square tests were performed to compare psychological health problems with socio-demographic characteristics, whereas Multivariate Logistic Regression Analysis was run to know the risk factors for psychological health problems. Results show that the majority of respondents were male (63.8\%), unmarried (58.5\%), 25 to 40 years old (78.5\%) and working as Lecturers or Assistant Professors (77\%), thus their job experience was 05 to 10 years. There was a significant difference in prevalence of psychological health problems in terms of socio-demographic characteristics of respondents. The psychological health problems were prevailing more among male, unmarried, less experienced and junior faculty positions. Results regarding risk factors for psychological health problems showed that Lecturers and Assistant Professors within the age group of 21 to 40 years, having five to ten years of job experience were more likely to develop psychological health problems. Furthermore, respondents exposed to excessive workload, interpersonal and emotional demands were also more likely to develop psychological health problems. Therefore, it was concluded that the psychological health disorder is a documented public health concern in the academia of Pakistan and it needs immediate corrective measures both at individual and institutional levels.

\section{Conceptual Framework}

The study investigated the different psychological health's risk factors in highly capitalize human economy. The term 'Human Capital' used in this study is for the academicians that are well trained, educated and sensible and they contributed to the economic development of a country. Due to the highly competitive environment, the academicians face multiple challenges. However, this competition sometimes. Figure 1 shows the risk factors associated with the psychological health in academicians. 


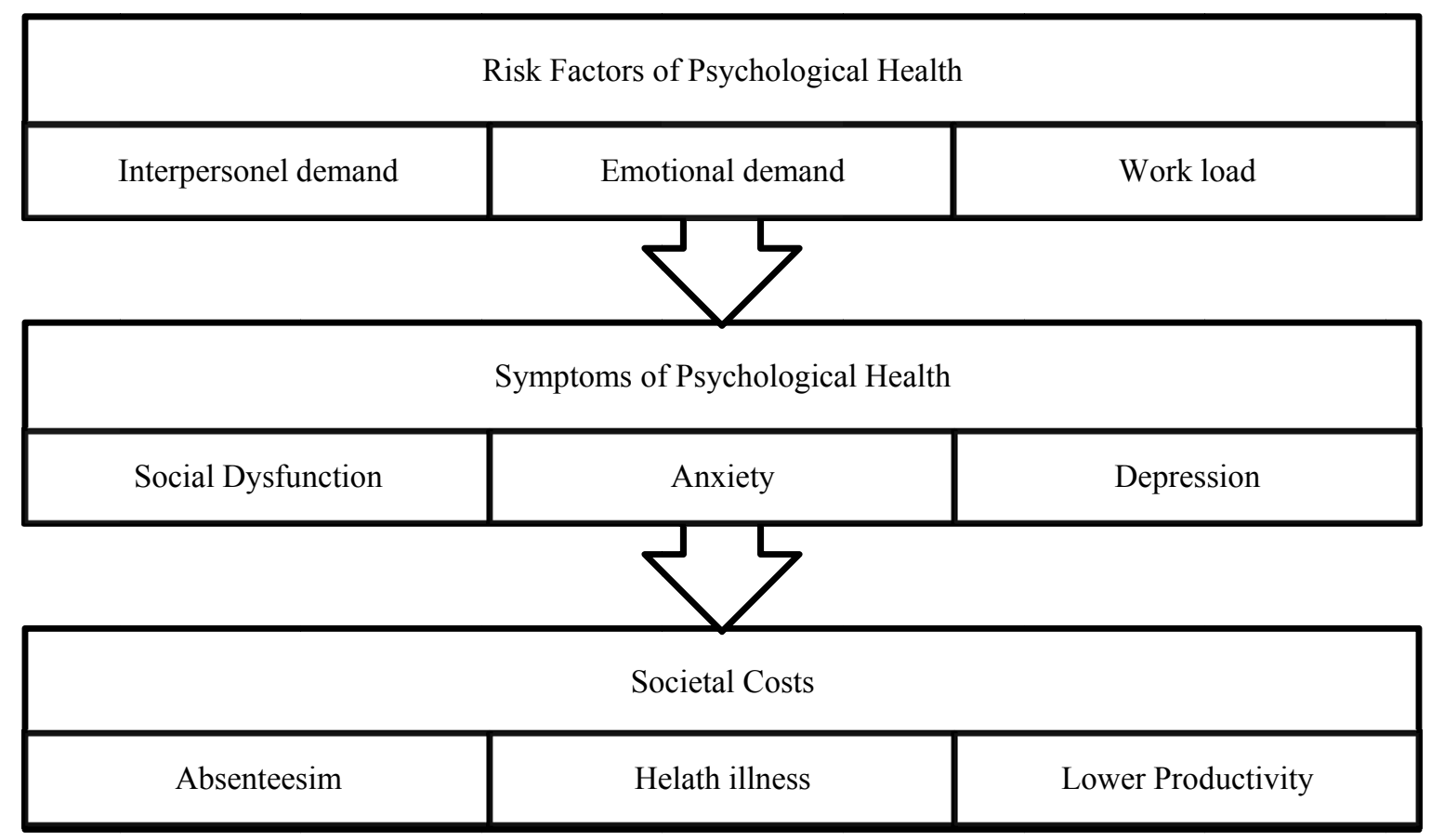

Figure 1. Conceptual framework of the study

Source: Adapted from Gillespie et al. (2001), Henderson et al. (2011), Best et al. (1997).

The conceptual framework of the study shows the three main risk factors are associated with the psychological health, including 'interpersonal demand' measured by three scales i.e., faculty stress index scale (Grnekh et al., 1986), problematic parents' behavior scale (Prakke et al., 2007) and organizational stress scale (Friesen and Williams, 1985). The second risk factor is 'emotional demand' which is measured by emotion work requirements scale (Best et al., 1997), and finally, the third risk factor is 'work load' measured by faculty stress index. Gillespie et al. (2001) indicate five symptoms of psychological health, including anxiety, depression, social dysfunction, cynicism and detachment, while three main symptoms of psychological health were assessed i.e., social dysfunction, anxiety and depression. In Pakistan's academia, there are a number of plausible problems faced by the academicians including time constraint, work load, challenging students, multiple roles, insufficient rewards, job intensity, inadequate resources, tight institutional policies and poor working conditions (Khan et al,. 2014). For these multiple reasons, MacAnespie (1978) indicated three major outcomes, i.e., physical punishment, deliver inconsistent lectures and poor personal habits. Henderson et al. (2011) shows the impact of psychological stress on the quality of institutions, i.e., absenteeism, health illness and lower productivity. The present study also indicates these three stressors as a societal cost of the country or for the institutions. Finally, the study borrows the socio-demographic characteristics of the academicians from the work of Kataoka et al. (2010) which includes age, sex, marital status, work position and work experience, etc. These characteristics have a considerable impact on the teachers' psychological health in Pakistan.

\section{Methods and Design}

\subsection{Respondents}

The respondents of current study included academic staff members from selected universities of Pakistan. In this regard a multi-stage sampling was done by initially selecting three regions of Pakistan, i.e. Islamabad, Khyber Pakhtunkhwa and Northern Punjab and as separate clusters. It was done because it was not practically possible for the researcher to collect data from all parts of the country. Details about three geographical regions is clear from Table 1. 
Table 1. Division of universities in three geographical regions

\begin{tabular}{lcc}
\hline Geographical regions & Number of Universities & Number of Teachers \\
\hline Islamabad Region & 16 & 2300 \\
North Punjab Region & 07 & 675 \\
Khyber Pakhtunkhwa Region & 13 & 1770 \\
\hline
\end{tabular}

In the second step, twelve universities were selected on the basis of following population parameters of interests:

1) Only those universities were selected which were geographically assessable

2) The science and technology based universities were selected because they are actively engaged in activities related to science and technology. Such universities can provide technological solutions to the stakeholders. The International Standard Nomenclature set by UNESCO has included Natural Science, Engineering, Medical and Agricultural Sciences as technological areas (UNESCO Nomenclature, 1988).

3) Finally, universities with several departments and programs were selected because teachers working within big universities are expected to suffer from a broad range of work stressors.

Table 2 shows that the universities are selected according to population parameters of interests. The universities are both from public as well as private sectors and are existing within the accessible geographical regions. Finally, these universities are related to science \& technology.

Table 2. Universities selected for data collection

\begin{tabular}{lcc}
\hline Name of University and Region & Nature & Number of Teachers \\
\hline Islamabad Region & Public & 263 \\
International Islamic University & Public & 282 \\
National University of Science \& Technology & Private & 265 \\
Riphah International University & Private & 120 \\
Iqra University, Islamabad & Public & 275 \\
COMSATS Institute Information Technology & & \\
Northern Punjab & Public & 173 \\
University of Eng and Tech, Taxila & Public & 112 \\
Aird Agriculture University, Rawalpindi & Private & 115 \\
University of Wah, Wah Cantt & & \\
Khyber Pakhtunkhwa (Central) & Public & 208 \\
University of Eng and Tech, Peshawar & Public & 251 \\
University of Peshawar & Private & 190 \\
Sarhad University of Information Technology & Public & 226 \\
Agriculture University Peshawar & & \\
\hline
\end{tabular}

The respondents in each cluster were divided into strata according job positions. In the last stage, a Simple Random Sampling method was utilized for choosing academic staff within each stratum. It was done because the number of academic staff was fixed and previously known from the websites of universities. Thus, each sampling unit had equal probability to be selected from each stratum. The sample size was taken in proportion to size of stratum through following formula provided by Yamane (1967, p. 886).

$$
n=\frac{N}{1+N(e)^{2}}
$$

Where $(n)$ is a sample size, $(N)$ is population size, and $(e)$ is the level of accuracy. For small population sizes the precision levels were kept high and vice versa. Following the formula mentioned above, sample size of 1189 was 
taken from a total population of $\mathrm{N}=2480$, as clear from Table 3 .

Table 3. Distribution of population and sample

\begin{tabular}{|c|c|c|c|c|c|c|c|c|}
\hline Name of University \& Region & $\begin{array}{l}\text { Prof } \\
(\mathrm{N})\end{array}$ & $\begin{array}{l}\text { Prof } \\
(n)\end{array}$ & $\begin{array}{c}\text { Asso } \\
\text { Prof }(\mathrm{N})\end{array}$ & $\begin{array}{c}\text { Asso } \\
\operatorname{Prof}(n)\end{array}$ & $\begin{array}{l}\text { Asst } \\
\text { Pro }(\mathrm{N})\end{array}$ & $\begin{array}{c}\text { Asst } \\
\operatorname{Prof}(n)\end{array}$ & $\begin{array}{l}\text { Lect } \\
(\mathrm{N})\end{array}$ & $\begin{array}{l}\text { Lect } \\
(n)\end{array}$ \\
\hline $\begin{array}{l}\text { Islamabad Region } \\
\text { International Islamic University }\end{array}$ & 35 & 22 & 28 & 10 & 89 & 36 & 113 & 46 \\
\hline $\begin{array}{c}\text { National University of Science } \\
\text { \& Technology }\end{array}$ & 36 & 22 & 39 & 26 & 97 & 38 & 110 & 45 \\
\hline Riphah International University & 22 & 12 & 42 & 30 & 93 & 37 & 106 & 43 \\
\hline Iqra University, Islamabad & 18 & 08 & 23 & 12 & 99 & 40 & 135 & 54 \\
\hline $\begin{array}{l}\text { COMSATS Institute } \\
\text { Information Technology }\end{array}$ & 07 & 03 & 10 & 05 & 37 & 10 & 66 & 35 \\
\hline Northern Punjab & & & & & & & & \\
\hline $\begin{array}{l}\text { University of Engineering and } \\
\text { Technology, Taxila }\end{array}$ & 08 & 05 & 13 & 06 & 38 & 20 & 56 & 36 \\
\hline $\begin{array}{c}\text { University of Aird Agriculture, } \\
\text { Rawalpindi }\end{array}$ & 28 & 10 & 38 & 25 & 63 & 26 & 44 & 30 \\
\hline University of Wah, Wah & 09 & 06 & 21 & 12 & 43 & 28 & 39 & 28 \\
\hline \multicolumn{9}{|l|}{ Khyber Pakhtunkhwa } \\
\hline $\begin{array}{l}\text { University of Engineering and } \\
\text { Technology, Peshawar }\end{array}$ & 18 & 08 & 36 & 25 & 58 & 33 & 96 & 39 \\
\hline Peshawar University & 24 & 12 & 43 & 28 & 67 & 30 & 92 & 37 \\
\hline $\begin{array}{l}\text { Sarhad University of } \\
\text { Information Technology }\end{array}$ & 32 & 15 & 44 & 29 & 48 & 30 & 127 & 51 \\
\hline $\begin{array}{c}\text { Agriculture University, } \\
\text { Peshawar }\end{array}$ & 09 & 05 & 17 & 07 & 62 & 28 & 102 & 41 \\
\hline
\end{tabular}

\subsection{Data Collection and Measurement}

Data was collected through a self-reported and administered questionnaire. It consisted of the following sections:

\subsection{Socio-Demographic Characteristics}

The Socio-demographic information included sex, age, matrimonial status, job position and experience.

\subsection{Risk Factors of Psychological Health}

Academicians are exposed to variety of risk factors, however, data was collected about three risk factors, i.e. Interpersonal Demands, Emotional Demands and Workload through five points Likert scale (01 Strongly Disagree to 05 Strongly Agree). The Interpersonal demands included interface with students, parents and colleagues. Interface with students was assessed by 02 items of Gmelch, Wilke, and Lovrich's (1986) Faculty Stress Index. Dealings with parents was assessed by 02 items of Problematic Parents Behaviors Scale made by Prakke, Peet, and Wolf (2007), while dealing with colleagues was assessed by 02 items of Organizational Stress Scale developed by Friesen and William (1985). The Emitional demands included exhibiting positive emotions. It was measured by 04 items of Best, Downey, Jones's (1997) Emotion Work Requirements Scale. Finally, Workload was assessed by the 04 items of Faculty Stress Index developed by Gmelch, Wilke, \& Lovrich's (1986). The intensity of each risk factor was determined by calculating its low, mild and high scores with Likert scoring procedure. For Interpersonal Demands, a score of 10 and above was considered as low. A score of 15 and above was considered as mlid, whereas score of 20 and above was considered as high. Similarly for Emotional Demands and Workload, a score of 05 and above was considered as low. A score 10 and above was considered as mild, while a score of 15 and above was considered as high. 


\subsection{Symptoms of Psychological Health Problems}

The symptoms of psychological health were measured by General Health Questionnaire (GHQ) formulated by Goldberg. For this purpose, nine items were taken from GHQ: 12 formulated by Goldberg \& Williams (1988) and three items were taken from GHQ: 28 formulated by David Goldberg (1972). It was done to ensure that each psychological health symptom is measured distinctively. All items were measured on 4-point Likert scale $(0=$ less than usual; $1=$ no more than usual; $2=$ rather more than usual; $3=$ much more than usual). Likewise, scores for each symptom were calculated by Likert Scoring procedure as recommended by David Goldberg (1972). In the current study, the score for Social Dysfunction ranged from 0 to 15, whereas the score for Anxiety ranged from 0 to 12 and for Depression it ranged from 0 to 09. A score of 10 or more was considered as Social Dysfunction, while a score of 08 or more was considered as Anxiety and a score of 06 or more was considered as Depression.

\subsection{Data Collection Process}

Data was collected by online circulation of the questionnaires among academic staff members in the selected twelve universities. In this regard email addresses of academic staff members were taken from websites of universities. Participants in each university were sent separate emails containing online link to the questionnaires and data collection permission letter issued by Deputy Dean, Faculty of Management, Universiti Teknologi Malaysia, Malaysia. The participants were requested to fill the online questionnaire. The participants who were willing to participate in the study finally filled the questionnaires (Note: The data collection process was part of the researcher's PhD work at Universiti Teknologi Malaysia, Malaysia). In a time period of seven months, 912 questionnaires were online recorded in a data base. Data from the questionnaires was initially screened by using MS Excel and IBM SPSS 20 and it was found that 132 questionnaires contained missing data. Later the normality analyses were done and it was found that 31 questionnaires had normality issues. Therefore, finally 749 questionnaires were chosen for further analysis.

\subsection{Data Analysis}

Data was examined by using both descriptive and inferential statistics. Descriptive analyses were performed on demographic data. Initially the demographic data was presented with frequency table. The prevalence of each symptom of psychological health problems was found out by calculating its relative scores and later on compared with demographic characteristics. In this regard Chi-square tests $\left(X^{2}\right)$ were run to observe such association. Finally, Multivariate Logistic Regression analysis (Hosmer, Lemeshow, \& Sturdivant, 2013) was run to know risk factors for psychological health problems by reporting Odds Ratios with $96 \%$ Confidence Intervals.

\section{Results}

\subsection{Demographic Characteristics of Respondents}

Table 4 shows that $63.81 \%$ respondents were male and $36.21 \%$ were female. Furthermore, $58.51 \%$ were single and $41.51 \%$ were married. Finally, $79.0 \%$ respondent were 25 to 40 years old that is reason most of respondents (77\%) were either Assistant Professors or Lecturers having on average five to fifteen years of work experience. Actually human life is divided three major stages, i.e. early adult shift (20 years and onward age ), mid-life shift (30 years and onward age) and late adult shift (40 years and onward age) (Levinson \& Darrow, 1978). Table 4 shows that about $79 \%$ of respondents are within age category of 21 to 40 years, such people are characterized by adjustment to life changes and transitions, therefore they are very prone to demanding experiences and psychological problems (Kail \& Cavanaugh, 2008). 
Table 4. Socio-demographic profile of respondents

\begin{tabular}{lcc}
\hline Characteristics & Number & Percentage (\%) \\
\hline Sex & & \\
$\quad$ Male Respondents & 479 & 64.0 \\
$\quad$ Female Respondents & 270 & 36.0 \\
Age & & \\
20-30 years & 367 & 49.0 \\
31-40 years & 221 & 29.5 \\
41-50 years & 105 & 14.0 \\
51-60 years & 56 & 7.50 \\
Marital Status & & \\
Single & 438 & 58.5 \\
Married & 311 & 41.5 \\
Job Position & & \\
Lecturer & 331 & 44.2 \\
Assistant Professor & 246 & 32.8 \\
Associate Professor & 101 & 13.5 \\
$\quad$ Professor & 71 & 09.5 \\
Work Experience & & \\
$<05$ year & 87 & 11.6 \\
06-10 years & 332 & 44.3 \\
11-15 years & 118 & 15.8 \\
16-20 years & 129 & 17.2 \\
21-25 years & 43 & 05.7 \\
26-30 years & 23 & 03.1 \\
Above 30 years & 17 & 02.3 \\
\hline
\end{tabular}

\subsection{Prevalence of Psychological Health Problems}

Overall, 50\% respondents had Anxiety symptoms, while 49\% respondents had Social Dysfunction and Depression symptoms. The mean score for anxiety was 7.76, whereas it was 9.65 for social dysfunction and 5.60 for depression. It means that respondents experienced a mild level of anxiety, social dysfunction and depression related symptoms. The prevalence of psychological health problems varied in accordance with socio-demographic characteristics of respondents. In this regard the relationship between demographic characteristics and psychological health problems was assessed by Pearson Chi-square tests. Results show that majority of demographic characteristics were significantly related to the psychological health problems. The symptoms of anxiety, depression and social dysfunction were prevailing among both genders; however, on average its rate was high among male faculty members, unmarried faculty members, 20 to 40 years old faculty members having 05 to 10 years work experience and holding positions of Lecturer or Assistant Professors, as clear from Table 5 . 
Table 5. Association between demographic characteristics and psychological health problems

\begin{tabular}{|c|c|c|c|c|c|c|}
\hline $\begin{array}{c}\text { Demographic } \\
\text { Characteristics }\end{array}$ & Anxiety & $\begin{array}{c}\text { Chi-Square } \\
\text { Df }(p)\end{array}$ & Depression & $\begin{array}{c}\text { Chi-Square } \\
\text { Df }(p)\end{array}$ & $\begin{array}{c}\text { Social } \\
\text { Dysfunction }\end{array}$ & $\begin{array}{c}\text { Chi-Square } \\
\text { Df }(p)\end{array}$ \\
\hline \multicolumn{7}{|l|}{$\operatorname{Sex}$} \\
\hline Male & 231 & 26.27 & 234 & 6.8 & 223 & 22.75 \\
\hline Female & 142 & $13(0.016)$ & 132 & $10(0.737)$ & 145 & $15(0.090)$ \\
\hline \multicolumn{7}{|l|}{ Age } \\
\hline $20-30$ years & 164 & & 158 & & 165 & \\
\hline $31-40$ years & 130 & & 135 & & 135 & \\
\hline $41-50$ years & 51 & 42.39 & 49 & 22.36 & 44 & 49.53 \\
\hline 51-60 years & 28 & $39(0.327)$ & 24 & $30(0.841)$ & 24 & $45(0.297)$ \\
\hline \multicolumn{7}{|l|}{ Marital Status } \\
\hline Single & 218 & 23.35 & 223 & 12.46 & 221 & 13.15 \\
\hline Married & 155 & $13(0.038)$ & 143 & $10(0.255)$ & 147 & $15(0.597)$ \\
\hline \multicolumn{7}{|l|}{ Job Position } \\
\hline Lecturer & 152 & & 162 & & 157 & \\
\hline Assistant Prof & 135 & & 132 & & 133 & \\
\hline Associate Prof & 48 & 54.51 & 45 & 24.41 & 41 & 57.91 \\
\hline Professor & 38 & $39(0.051)$ & 27 & $30(0.767)$ & 37 & $45(0.026)$ \\
\hline \multicolumn{7}{|l|}{ Work Experience } \\
\hline$<05$ year & 50 & & 49 & & 47 & \\
\hline $06-10$ years & 175 & & 168 & & 169 & \\
\hline $11-15$ years & 47 & & 57 & & 52 & \\
\hline $16-20$ years & 60 & & 55 & & 58 & \\
\hline $21-25$ years & 16 & & 21 & & 22 & \\
\hline $26-30$ years & 13 & 157.53 & 09 & 102.30 & 11 & 146.86 \\
\hline Above 30 years & 12 & $78(0.000)$ & 07 & $60(0.001)$ & 09 & $90(0.000)$ \\
\hline
\end{tabular}

Note. $p$ values are related with Chi-square test.

\subsection{Relationship between Socio-Demographic Profile, Work Stressors and Psychological Health}

Table 6 presents risk factors for the symptoms of anxiety, depression and social dysfunction. In this regard, risk factors like gender and marital status were not significantly associated with the psychological health problems; however, risk factors like age, job position, work experience, interpersonal demands, emotional demands and workload were significantly associated with the psychological health problems. The details show that respondents in the age group of 20 to 40 years, having 05 to 10 years work experience and holding job positions of lecturer and assistant professors had high odds for psychological health problems. Furthermore, work related risk factors like interpersonal demands, emotional demands and workload had also high odds. Therefore, lecturer and assistant professors having 20 to 40 years age, 05 to 10 years' experience that were exposed to risk factors like interpersonal demands, emotional demands and workload were more likely to experience symptoms of anxiety, depression and social dysfunction. 
Table 6. Results of multivariate logistic regression

\begin{tabular}{|c|c|c|c|}
\hline Factors & Anxiety & Depression & Social Dysfunction \\
\hline & OR $(95 \%$ CI) & OR $(95 \%$ CI $)$ & OR $(95 \%$ CI $)$ \\
\hline \multicolumn{4}{|l|}{$\operatorname{Sex}$} \\
\hline Male & $1.159(0.82-1.62)$ & $1.205(0.86-1.68)$ & $1.231(0.881-1.71)$ \\
\hline Female & Reference & Reference & Reference \\
\hline \multicolumn{4}{|l|}{ Age } \\
\hline 20-30 years & $5.371(2.35-12.23)^{*}$ & $5.368(2.35-12.24)^{*}$ & $5.470(2.39-12.47)^{*}$ \\
\hline $31-40$ years & $6.014(2.62-13.76)^{*}$ & $5.994(2.61-13.73)^{*}$ & $6.115(2.66-14.01)^{*}$ \\
\hline $41-50$ years & $2.737(1.11-6.72)^{* *}$ & $2.522(1.02-6.22)^{* *}$ & $2.532(1.026-6.2)^{* *}$ \\
\hline $51-60$ years & Reference & Reference & Reference \\
\hline \multicolumn{4}{|l|}{ Marital Status } \\
\hline Single & $0.961(0.686-1.34)$ & $0.988(0.705-1.38)$ & $0.991(0.707-1.38)$ \\
\hline Married & Reference & Reference & Reference \\
\hline \multicolumn{4}{|l|}{ Job Position } \\
\hline Lecturer & $173.91(33.3-906.3)^{*}$ & $148.49(28.76-766.61)^{*}$ & $148.80(28.7-769.4)^{*}$ \\
\hline Assistant Professor & $163.28(30.5-872.6)^{*}$ & $137.44(25.97-727.44)^{*}$ & $138.81(26.1-735.8)^{*}$ \\
\hline Associate Professor & $30.91(6.27-152.4)^{*}$ & $32.35(6.54-159.90)^{*}$ & $33.32(6.53-159.9)^{*}$ \\
\hline Professor & Reference & Reference & Reference \\
\hline \multicolumn{4}{|l|}{ Work Experience } \\
\hline$<05$ year & $0.121(1.01-1.52)^{* *}$ & $0.153(0.018-1.32)^{* *}$ & $0.150(0.017-1.30)^{* *}$ \\
\hline $06-10$ years & $1.090(1.01-1.74)^{* *}$ & $0.101(0.012-0.84)^{* *}$ & $0.102(0.012-0.85)^{* *}$ \\
\hline $11-15$ years & $0.112(0.01-0.96)^{* *}$ & $0.123(0.014-1.06)^{* *}$ & $0.121(0.014-1.04)^{* *}$ \\
\hline $16-20$ years & $0.778(0.048-1.286)$ & $0.272(0034-2.15)$ & $0.269(0.034-2.13)$ \\
\hline 21-25 years & $0.293(0.03-2.29)$ & $0.730(0.080-6.65)$ & $0.717(0.079-6.55)$ \\
\hline $26-30$ years & $0.687(0.07-6.24)$ & $0.210(0.062-0.098)$ & $0.322(0.012-0.078)$ \\
\hline Above 30 years & Reference & Reference & Reference \\
\hline \multicolumn{4}{|l|}{ Interpersonal Demands } \\
\hline Low & $8.304(4.97-13.85)^{*}$ & $8.678(5.200-14.483)^{*}$ & $8.67(5.200-14.48)^{*}$ \\
\hline Mid & $3.831(2.141-6.856)^{*}$ & $2.678(1.484-4.834)^{*}$ & $2.84(1.582-5.133)^{*}$ \\
\hline High & Reference & Reference & Reference \\
\hline \multicolumn{4}{|l|}{ Emotional Demands } \\
\hline Low & $3.85(2.84-6.89)^{*}$ & $3.664(2.174-6.176)^{*}$ & $3.716(2.205-6.263)^{*}$ \\
\hline Mid & $7.200(3.716-13.95)^{*}$ & $7.200(3.716-13.951)^{*}$ & $7.200(3.716-13.95)^{*}$ \\
\hline High & Reference & Reference & Reference \\
\hline \multicolumn{4}{|l|}{ Workload } \\
\hline Low & $12.81(7.00-23.64)^{*}$ & $13.39(7.317-24.524)^{*}$ & $13.39(7.317-24.52)^{*}$ \\
\hline Mid & $6.484(3.350-12.55)^{*}$ & $4.635(2.382-9.020)^{*}$ & $4.910(2.526-9.543)^{*}$ \\
\hline High & Reference & Reference & Reference \\
\hline
\end{tabular}

*Significant at $\mathrm{p}<0.001 ; *$ Significant at $\mathrm{p}=0.005$.

\section{Discussion}

Teaching and scholarly activities are globally recognized for their demanding nature. Teachers develop unwanted 
physical and psychological symptoms after they are exposed to different work stressors (Gillespie et al., 2001). This study has initially examined the prevalence of psychological health problems in universities of Pakistan and then determined its risk factors. Findings of this study revealed that prevalence of psychological health problem varied in accordance with to socio-demographic characteristics. The symptoms of Anxiety, Depression and Social Dysfunction were prevailing both among male and female; however, its prevalence was high among the single, young, less experienced, and junior faculty members. The previous research has reported similar results. For example Kataoka et al. (2014) carried study on psychological health conditions of faculty members in Japan and found that symptoms of Anxiety, Depression and Social Dysfunction were prevailing among both genders, where its prevalence was high among female faculty members. Moreover, the incidence of such symptoms was high among lecturers as compared to professors. Similarly, Jaber and Al-Zoubi (2012) conducted a study on burnout and psychological health problems of faculty members working in Jordanian universities. They found that psychological health problems were prevailing within both genders, where its prevalence was higher among female respondents. Furthermore, the Assistant Professors, having age of 36 years and above with average experience of 06 and above years had a high incidence of psychological health problems. Such results suggest that young aged, junior teachers with less experience are more likely to affect from psychological health problems because they are more exposed to work related stressors and they have weak stress coping capacities as compared senior faculty members, who have relatively strong stress coping capacities due to attaining maturity in life.

The current study has also determined the risk factors for psychological health problems in academia of Pakistan. The results show risk factors like age, job position, work experience, interpersonal demands, emotional demands and workload were significantly associated with the psychological health problems. Such findings are in concurrence with previous research. For example Kovess-Masféty et al. (2006) carried out a cross-sectional survey on health problems of teachers and found that risk factors like age, marital status, educational level, work experience and working environment characteristics have a positive relationship with the symptoms of anxiety and depression. On the other hand, Bauer et al. (2007) and Ferguson et al. (2012) further found that work factors like interaction with students, workload, time constraints and multiple roles were major predictors of Anxiety, Depression, Obsessive Compulsive and Somatization disorders among German and American teachers (Bauer et al., 2007; Ferguson, Frost, \& Hall, 2012). It is because in different professions certain psychosocial work characteristics (e.g. particular genders, job positions, work experience and unwanted working conditions etc.) act as potential risk factors for psychological health problems among employees (Andrea et al., 2004; Andrea, Bültmann, van Amelsvoort, \& Kant, 2009) particularly in teaching profession (Tang, Leka, \& MacLennan, 2013). Teaching has now become complex and ever demanding. Now teachers are supposed to meet the needs of modern educational system (Subrahmanyam, 2011). That is why teachers are more likely to experience the psychological health problems as they are more exposed to the unwanted working conditions.

\section{Conclusion}

Findings of this study have confirmed that psychological health problems are prevailing in academia of Pakistan. It is because the working environment of educational institutions in Pakistan is changing, the academic staff members are getting exposed to certain work stressors (e.g. Workload, interaction with students \& parents, emotional demands, time pressure, resource constraints etc.) consequently they are at high risk of experiencing different psychological health problems. In addition the individual characteristics (e.g. Gender, age, job position, work experience e.t.c) of academic staff are also potential risk factors for psychological health problems. Therefore, it has been concluded that psychological health problems is a recognized issue in universities of Pakistan. The academic staff should be given stress management training for developing awareness about potential risk factors of psychological health problems. It can also facilitate teaching staff to build up stress-coping capacities. At intuitional level, the management of universities need to provide a favorable working environment to academic staff so that negative impact of work stressors could be minimized. Moreover, the team work should be promoted and interpersonal conflicts should be resolved. At policy and government level, the Higher Education Commission and Ministry of Education, Pakistan should take steps to enhance budgets of educational institutions and devise adaptable policies. The universities should given institutional autonomy and participation in policy formulation processes. The Higher Education Commission should pass out legislation specifically related to work stress, work place design, health and safety of teachers because it has been noticed that majority of countries don't have such legislations (Jenkins, 2003). All these interventions will improve the health outcomes of academic staff in Pakistan.

\section{References}

Andrea, H., Bültmann, U., Beurskens, A. J. H. M., Swaen, G. M. H., Van Schayck, C. P., \& Kant, I. J. (2004). 
Anxiety and depression in the working population using the HAD Scale, psychometrics, prevalence and relationships with psychosocial work characteristics. Social psychiatry and psychiatric epidemiology, 39(8), 637-646. http://dx.doi.org/10.1007/s00127-004-0797-6

Andrea, H., Bültmann, U., van Amelsvoort, L. G., \& Kant, Y. (2009). The incidence of anxiety and depression among employees - the role of psychosocial work characteristics. Depression and Anxiety, 26(11), 1040-1048. http://dx.doi.org/10.1002/da.20516

Bauer, J., Unterbrink, T., Hack, A., Pfeifer, R., Buhl-Grießhaber, V., Müller, U., . . . Wirsching, M. (2007). Working conditions, adverse events and mental health problems in a sample of 949 German teachers. International archives of occupational and environmental health, 80(5), 442-449. http://dx.doi.org/10.1007/s00420-007-0170-7

Best, Downey, \& Jones. (1997). Incumbent perceptions of emotional work requirements. Paper presented at the 12th annual conference of the Society for Industrial and Organizational Psychology, St. Louis, MO.

Ferguson, K., Frost, L., \& Hall, D. (2012). Predicting teacher anxiety, depression, and job satisfaction. Journal of Teaching and Learning, 8(1).

Friesen, D., \& Williams, M. (1985). Organizational stress among teachers. Canadian Journal of Education/Revue canadienne de l'education, 10(1), 13-34.

Gillespie, N. A., Walsh, M., Winefield, A. H., Dua, J., \& Stough, C. (2001). Occupational stress in universities: Staff perceptions of the causes, consequences and moderators of stress. Work \& Stress, 15(1), 53-72. http://dx.doi.org/10.1080/02678370117944

Gmelch, W., Wilke, P. K., \& Lovrich Jr, N. (1986). Dimensions of stress among university faculty: Factor-analytic results from a national study. Research in Higher Education, 24(3), $266-286$. http://dx.doi.org/10.1007/BF00992075

Goldberg, D. (1972). The detection of psychiatric illness by questionnaire. Oxford University Press.

Goldberg, D., \& Williams, P. (1988). A User's Guide to the General Health Questionnaire. NFER-NELSON.

Henderson, M., Harvey, S., Øverland, S., Mykletun, A., \& Hotopf, M. (2011). Work and common psychiatric disorders. Journal of the Royal Society of Medicine, 104(5), 198-207. http://dx.doi.org/10.1258/jrsm.2011.100231

Hosmer, D. W., Lemeshow, S., \& Sturdivant, R. X. (2013). Applied Logistic Regression. Wiley. http://dx.doi.org/10.1002/9781118548387

Jaber, F., \& Al-Zoubi, M. (2012). The Relationship between Work Burnout and Employees' Mental Health as Measured by GHQ-28: A Field Study Using a Sample of University Lecturers. International Journal of Business and Management, 7(24), 44. http://dx.doi.org/10.5539/ijbm.v7n24p44

Jenkins, R. (2003). Supporting governments to adopt mental health policies. World Psychiatry, $2(1), 14$.

Kail, R. V., \& Cavanaugh, J. C. (2008). Human Development: A Life-Span View. Wadsworth Cengage Learning.

Kataoka, M., Ozawa, K., Tomotake, M., Tanioka, T., \& King, B. (2014). Occupational stress and its related factors among university teachers in Japan. Health, 6, 299. http://dx.doi.org/10.4236/health.2014.65043

Khan, A., Yusoff, R. B. M., \& Azam, K. (2014). Factors of Job Stress among university teachers in Pakistan A conceptual review. Journal Of Management Info, 2(1).

Kovess-Masféty, V., Sevilla-Dedieu, C., Rios-Seidel, C., Nerrière, E., \& Chee, C. C. (2006). Do teachers have more health problems? Results from a French cross-sectional survey. BMC Public Health, 6(1), 101. http://dx.doi.org/10.1186/1471-2458-6-101

Laghar, J. (2013). Higher Education Commission Serving as an Engine for the Socio-economic Development of Pakistan. Retrieved from http://www.hec.gov.pk/MediaPublication/HECPublication/Documents/Media.pdf

Levinson, D. J., \& Darrow, C. (1978). The Seasons of a Man's Life. Ballantine Books.

MacAnespie, H. (1978). Mental illness in school teachers. British Medical Journal, 2(6132), 257. http://dx.doi.org/10.1136/bmj.2.6132.257

Moreno-Abril, O., de Dios Luna-del-Castillo, J., Fernández-Molina, C., Jurado, D., Gurpegui, M., Lardelli-Claret, P., \& Gálvez-Vargas, R. (2007). Factors associated with psychiatric morbidity in Spanish schoolteachers. Occupational medicine, 57(3), 194-202. http://dx.doi.org/10.1093/occmed/kqm013 
PES. (2013). Pakistan Economic Survery. Retrieved from http://finance.gov.pk/survey/chapters_13/executive\%20summary.pdf

Prakke, B., Van Peet, A., \& Van der Wolf, K. (2007). Challenging parents, teacher occupational stress and health in Dutch primary schools. International Journal About Parents in Education, 1(4), 36-44.

Reevy, G., \& Deason, G. (2014). Predictors of depression, stress, and anxiety among non-tenure track faculty. Frontiers in psychology, 5(1), 1-17. http://dx.doi.org/10.3389/fpsyg.2014.00701

Rusli, B., Edimansyah, B., \& Naing, L. (2006). Prevalence and associated factors of stress in dental healthcare workers of a higher institution of learning in Kelantan. Archives of Orofacial Sciences, 1, 51-56.

Subrahmanyam. (2011). The paradigm shift in Teaching profession: Some thoughts. Retrieved from http://www.physics.iitm.ac.in/ manu/images/The_Good_teachers.pdf

Tang, J. J., Leka, S., \& MacLennan, S. (2013). The psychosocial work environment and mental health of teachers: a comparative study between the United Kingdom and Hong Kong. International archives of occupational and environmental health, 86(6), 657-666. http://dx.doi.org/10.1007/s00420-012-0799-8

UNESCO Nomenclature. (1988). Proposed international standard nomenclature for fields of science \& technology. United Nations Educational, Scientific and Cultural Organization.

Winefield, Boyd, Saebel, \& Pignata. (2008). Job Stress in University Staff. An Australian Research Study: Australian Academic Press.

Yamane, T. (1967). Statistics: an introductory analysis (2nd ed.). New York: Harper \& Row.

Yusoff, R., Khan, A., \& Azam, K. (2013). Job Stress, Performance and Emotional Intelligence in Academia. Journal of Basic and Applied Science Resesearch, 3(6), 1-8.

\section{Copyrights}

Copyright for this article is retained by the author(s), with first publication rights granted to the journal.

This is an open-access article distributed under the terms and conditions of the Creative Commons Attribution license (http://creativecommons.org/licenses/by/3.0/). 